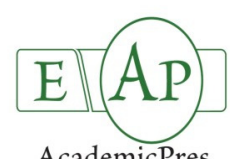

AcademicPres

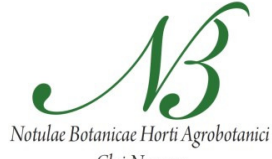

Cluj-Napoca

\title{
The Dynamics and Variability of Radial Growth in Provenance Trials of Norway Spruce (Picea abies (L.) Karst.) Within and Beyond the Hot Margins of its Natural Range
}

\author{
Neculae ȘOFLETEA ${ }^{1}$, Alexandru Lucian CURTU ${ }^{1}$, Mihai Liviu DAIA², \\ Marius BUDEANU ${ }^{3 *}$ \\ ${ }^{1}$ Transilvania University of Brasov, Department of Forest Sciences, Sirul Beethoven 1, 500123, Brassov, Romania; nic.sofletea@unitbv.ro; Lucian.curtu@unitbv.ro \\ ${ }^{2}$ University of Agronomic Science and Veterinary Medicine, Faculty of Agriculture, Forestry Department, 59 Mărăşti Boulevard, 01 1464, \\ Bucharest,Romania;mihai.daia@mp.rosilva.ro \\ ${ }^{3}$ Forest Research and Management Institute, Tree Genetics and Breeding Department, 13 Closca Street, 500040, \\ Braşov, Romania; budeanumarius@yahoo.com ('correspondingauthor)
}

\begin{abstract}
Multi-site field trials provide valuable data for the investigation of possible effects of environmental changes on forest tree species. We analyze the descendants of plus trees from 33 Norway spruce seed sources of Romanian Carpathians, at age 30, in four comparative field trials: two established in the natural range of species and two outside of it. The dynamics and variation of radial growth, earlywood and latewood were analyzed. The influence of populations, site conditions and climatic factors were also quantified. The provenances response in the four comparative trials was asymmetric for mean radial growth, but its dynamics was less favourable outside of the natural range. Analysis of variance showed significant differences $(\mathrm{P}<0.001)$ between the testing sites, but non-significant $(\mathrm{P}<0.05)$ for the populations. Populations $\mathrm{x}$ localities interaction was high $(\mathrm{P}<0.001)$ in the first half of the testing period, but decreased over time, becoming not significant at the age of 30 . At intrapopulational level, the average coefficient of variation for radial growth was higher outside the natural range, whereas the proportion of latewood decreased. The temperature in the first half of the growing season negatively influenced $(\mathrm{P}<0.001)$ the radial increment, but in the latewood proportion significat effects $(\mathrm{P} \square 0.05)$ were recorded only in trials located outside of the natural range. An increased variability of radial growth and a decrease of latewood proportion are expected in Norway spruce stands located at lower altitudes, towards the limits of the natural range. Our results may contribute to the sustainable management of Norway spruce forests within and outside its natural range.
\end{abstract}

Keywords: adaptive traits, climatic changes, growth-climate correlations, field trials, radial increments, wood characteristics.

\section{Introduction}

Norway spruce (Picea abies (L.) Karst.) is the keystone species of different types of complex forest ecosystems in the boreal and temperate zones of Europe (Castagneri et al., 2013; Koski et al., 1997; Rybniček et al., 2010). In the last 200 years, intensive spruce plantations were installed not only in its natural range, but also outside of it (Hannerz and Westin, 2005; Spiecker, 2000), which has influenced the distribution of populations and sometimes their adaptability to local environmental conditions (Kahle et al., 2005; Latalowa and van der Knaap, 2006). Negative ecological consequences have occurred especially in areas with extreme climate events (Carrer et al., 2012; Schütz et al., 2006). It considers the existence of asymmetric response of populations to these environmental changes (Mátyás et al., 2010), which can be evaluated by simulations, but also by ecological investigations under different climatic conditions (Andreassen et al., 2006), in or/and outside the natural range.
Norway spruce plantations continue to be established outside the natural range, particularly as a result of actions targeting carbon sequestration (Olofsson et al., 2011; Peichl et al., 2006).

Many studies carried out in natural populations or in field trials aimed at getting insight into the performance of Norway spruce at various altitudes, latitudes or along of gradients. Some of these approaches have evaluated the growth rate and fiber traits or the resistance to biotic or abiotic pests (Battipaglia et al., 2009; Mäkinen et al., 2002; Saren et al., 2004; Sawa et al., 2006; Skrøppa, 1994; Steffenrem et al., 2009). Other studies investigated the physiological response at various altitudinal levels or by gradiental analysis (Matyssek $e t$ al., 2009; Oleksyn et al., 2002). However, comparative data on performances of Norway spruce in its natural range and outside it is limited, particularly in the Romanian Carpathians.

The sustainable management of genetic resources is an important requirement (Matyssek et al., 2009; White et al., 2007) and includes multiple targets, such as the use of genetically 
266

improved forest reproductive material, adapted to the local environmental conditions. In this context, the comparative evaluation of Norway spruce response in field trials established in and outside its natural range may contribute to the improvement of silvicultural practices. Even more, data is needed for natural populations or crops at the limits of its natural range.

The adaptation of populations to the environmental conditions of the four trials, completed by the recommendation of valuable populations for use in similar environmental conditions in which they performed, was previously presented in Şofletea et al. (2012) and Şofletea and Budeanu (2015). In this paper are analyzed: $i)$ the dynamics of radial increments; ii) the inter- and intrapopulational variations of radial growths and the testing site influence; iii) the influence of climatic factors on annual growths.

\section{Materials and methods}

\section{Plant material, experimental design and sampling}

Ten plus-trees per stand were selected in 33 seed sources located throughout the natural range of Norway spruce in the Romanian Carpathians (location and geographical coordinates of the populations in Şofletea et al., 2012). The populations Coşna, Dorna Candrenilor, Frasin, Marginea, Moldovița, Stulpicani, Năsăud, Prundul Bârgăului, Rodna, Sânmartin, Toplița, Gurghiu, Sovata and Tarcău are from Eastern Carpathians, where the average annual temperature and precipitation are closer to the values registered for Gurghiu trial $\left(5.7^{\circ} \mathrm{C}\right.$ and $\left.810 \mathrm{~mm}\right)$. The populations Comandău, Nehoiu, Nehoiaşu, Braşov and Azuga are originated from Curvature Carpathians where the average annual temperature and precipitation are closer to the values registered for Brețcu trial $\left(4.8^{\circ} \mathrm{C}\right.$ and $\left.830 \mathrm{~mm}\right)$. The populations Domneşti, Orăştie, Bistra, Voineasa and Retezat are originated from Southern Carpathians where the average annual temperature and precipitation are closer to the values registered for Brețcu trial (4.8 ${ }^{\circ} \mathrm{C}$ and $830 \mathrm{~mm}$ ). The populations Bozovici, Văliug, Beliş, Turda, Beiuş, Dobreşti, Sudrigiu, Câmpeni and Gârda are originated from Western Romanian Carpathians where the average annual temperature and precipitation are approximately $6{ }^{\circ} \mathrm{C}$ and 800 $\mathrm{mm}$.

The seeds collected from ten trees per stand were mixed up and sowed in a nursery (at $45^{\circ} 18^{\prime} \mathrm{N}, 25^{\circ} 34^{\prime} \mathrm{E}, 745 \mathrm{~m}$ a.s.l.), resulting in a total of 33 samples of provenances. Each sample will be considered as a local population. Four field trials were established with two-year-old seedlings: two field trials (Bretcu and Gurghiu) in the natural range of species and other two field trials (Câmpina and Avrig) outside of the natural range, considered beyond the hot margins of natural distribution of Norway spruce in Carpathian area (Table 1). In each field trial the experimental design was incompletely balanced, type $6 \times 6$, with 3 replications and 49 seedlings per plot planted at 2 by $2 \mathrm{~m}$ spacing. Since there are 33 populations, three populations were repeated in each replication to complete the $6 \times 6$ experimental design.

\section{Data collection and analysis}

Core samples were collected at the breast height $(1.3 \mathrm{~m})$ from 9 trees of each population (3 per replication, belonging to the mean diameter category of population in each replication, age 30) in dormant season and with an increment borer. The annual radial increments (RI) and the values for latewood (LW) and earlywood (EW) were determined in the laboratory. To measure radial growth, a Rinntech LINTAB 5 tree-ring measurement station was
Table1. Location and climatic characteristics of field trials

\begin{tabular}{|c|c|c|c|}
\hline Trial & Location & $\begin{array}{l}\text { Average annual } \\
\text { temperature }\left({ }^{\circ} \mathrm{C}\right)\end{array}$ & $\begin{array}{c}\text { Average annual } \\
\text { precipitation }(\mathrm{mm})\end{array}$ \\
\hline \multicolumn{4}{|c|}{ In the natural range (INR) } \\
\hline Brețcu & $\begin{array}{l}1100 \mathrm{~m} \text { a.s.l. } \\
45^{\circ} 58^{\prime} 16^{\prime \prime} \mathrm{N} \\
26^{\circ} 24^{\prime} 12^{\prime \prime} \mathrm{E}\end{array}$ & 4.8 & 830 \\
\hline Gurghiu & $\begin{array}{l}1000 \mathrm{~m} \text { a.s.l. } \\
46^{\circ} 48^{\prime} 13^{\prime \prime} \mathrm{N} \\
25^{\circ} 03^{\prime} 58^{\prime \prime} \mathrm{E}\end{array}$ & 5.7 & 810 \\
\hline \multicolumn{4}{|c|}{ Outside the natural range (ONR) } \\
\hline Câmpina & $\begin{array}{l}570 \mathrm{~m} \text { a.s.l. } \\
45^{\circ} 11^{\prime} 11^{\prime \prime} \mathrm{N} \\
25^{\circ} 48^{\prime} 47^{\prime \prime} \mathrm{E}\end{array}$ & 9.3 & 645 \\
\hline Avrig & $\begin{array}{l}615 \mathrm{~m} \text { a.s.l. } \\
45^{\circ} 39^{\prime} 36^{\prime \prime} \mathrm{N} \\
24^{\circ} 26^{\prime} 12^{\prime \prime} \mathrm{E}\end{array}$ & 8.3 & 680 \\
\hline
\end{tabular}

used. TSAP Win software was used for data recording and primary processing. Each ring-width series was checked for crossdating and measurement errors using Cofecha software (Holmes, 1983).

Starting from the last annual ring, annual values for radial increment (RI) and latewood (LW) was registered and also the average values for 5-years intervals (RI/5y, LW/5y and \%LW/5y) were determined. Data were also processed to determine intra- and interpopulational coefficients of variation of radial increment (CVRI) and latewood (CVLW) in each comparative trial. A bifactorial ANOVA analysis was conducted in order to highlight the influences of testing site and population $\mathrm{x}$ locality interaction, according to the following model:

$$
\mathbf{x}_{\mathrm{ijk}}=\mathbf{m}+\boldsymbol{\alpha}_{\mathrm{i}}+\boldsymbol{\beta}_{\mathrm{i}}+\boldsymbol{\alpha}_{\mathbf{i} \mathrm{i}}+\mathbf{z}_{\mathrm{ijk}}
$$

where: $\mathrm{m}=$ overall average value, $\alpha_{\mathrm{i}}=$ component of $\mathrm{i}$ populations $(i=1 . . . a), \beta_{j}=$ component of $j \operatorname{localities}(j=1 . . . b), \alpha \beta_{i j}=$ interaction of $\mathrm{i}$ populations with $\mathrm{j}$ localities, $\varepsilon_{\mathrm{ijk}}=$ random error.

The normal distribution was checked with the Kolmogorov Smirnov test and Levene's test was used to assess variance homogeneity before applying ANOVA. The statistical significance was determined by using Fisher $(\mathrm{F})$ test for 5\%, 1\% and $0.1 \%$ transgression probability.

A matrix of correlation between annual/seasonal values of climatic data of tested sites (Table 6) and annual values of RI and $\% \mathrm{LW}$, respectively, was produced and analyzed. To eliminate the influence of age and for obtaining the growth standardized indices the ASTRANwin program was used (Cook and Krusic, 2006). Average climatic data for the last 25 years provided by the Romanian National Meteorological Administration were used. Data were collected from weather stations located closest to the field trials. STATISTICA ver. 10.0 software was used for data processing.

\section{Results and discussions}

\section{Dynamics of radial increment}

The evolution of radial growth as average values calculated every year for all populations, in each of the four testing sites is showed in Fig. 1. Maximum values of radial growths were recorded between (9) 10-11 years after planting, in both categories of field trials (Table 2). The two major testing variants (in the natural range of the species - INR and outside it - ONR, respectively) could not be differentiated with respect to the maximum radial growths: in each of them, the values were higher in one of the testing site $(6.901 \mathrm{~mm} /$ year in Avrig test - ONR, 
and $6.581 \mathrm{~mm} /$ year in Bretcu test - INR). However, the two tests indicated a similar pattern and for the average values of radial growths $(\mathrm{RI}=4.053 \mathrm{~mm} /$ year in Avrig and 4.104 $\mathrm{mm} /$ year in Brețcu trial).

Compared to the maximum radial growth (RImax), the mean radial growth (RI) decreased on average by $40.2 \%$ ONR (Avrig $=41.3 \%$; Câmpina $=39.1 \%)$ and by $36.0 \%$ INR (Brețcu $=37.6 \%$; Gurghiu $=34.3 \%$ ). This indicates the huge growing capacity of spruce in the first third of the testing period. In the last 5 years, the average value of annual radial growth has decreased by $13 \%$ in the two ONR tests, compared to the same period in INR tests, but clearly more in Câmpina field trial (16.5\%, Table 2). On average, ONR, the percentage ratio between the average radial growth of the last 5 years and their average for 25 years is $5.3 \%$ higher. On the other hand, in the two ONR field trials there was a higher decrease of the percentage ratio between maximum annual radial growth and the average in the last five years (on average, 69.6\% ONR and 64.4\% INR, respectively).

Among the populations originating from the lower limit of the natural range, it was noted the Dobreşti provenance (ranked 7 in Avrig test, 3 in Câmpina and Gurghiu), followed by Bozovici population that performed well in Avrig and Gurghiu trials (ranked 8 and 3, respectively), while Marginea population performed well only in the field trials established in ecological optimum of the species ( $1^{\mathrm{x}}$ in Bretcu and $6^{\mathrm{h}}$ in Gurghiu).

With regard to the periodical radial growths for five year intervals (RI/5y) and their dynamics, up the age of 10 , the values were higher in the two field trials located ONR, compared INR trials (Fig. 2). Compared to radial increments registered between 610 years, the values decreased 3 times in the last 5 years in ONR field trials, but only 2.5 times in INR field trials. Three marginal populations (Marginea, Dobreşti and Bozovici) did not register fluctuations of theirs ranking along the 5 years analyzed periods.

For all 33 populations, there were no significant differences between the two major variants (INR and ONR) in the first part of testing period. After that, the annual radial growth decreased particularly in Câmpina field trial. In both ONR field trials, the radial increment values were lower than those of INR tests especially in the last third of the evaluation period. The climatic conditions were less favourable in both ONR tests: low precipitation and higher temperatures during the growing season. This led to higher values of thermo-pluviometric factor between May and September (Şofletea et al., 2015), a climatic parameter considered very important for Norway spruce at the hot limit of its natural range (Schmidt-Vogt, 1977). As a consequence, the decrease of radial growth in the last decade, outside of the natural range, indicated the occurrence of stress caused by the combination low precipitation-high temperatures, because the consumption has increased as a result of previously accumulated biomass. Therefore, it is likely that the differences between INR and ONR field trials to increase in the future.

The pattern of the radial growth dynamics is similar both in INR and ONR field trials, explained by a polynomial function of 3rd degree. On the other hand, the dynamics of LW showed a linear pattern, but LW decrease with age was more evident in the INR tests.

Influences of different testing locations were also reported in a study conducted in Slovakia for 30 spruce provenances assessed at a tree age of 26 (Pacalaj et al., 2002), in four field trials distributed between 335 and $950 \mathrm{~m}$ altitude, and the smallest values of diameter were registered at the upper limit of the altitudinal transect.

\section{Dynamics of latewood proportion}

As shown in Fig. 1 (a, b, c and d), the latewood width decreased with age, particularly in the two INR tests, and also in the Avrig field trial (ONR). Unlike the dynamics of radial increments that vary by a polynomial model, LW decreased linearly, and the coefficient of determination indicated a good response of populations in Avrig, Brețcu and Gurghiu field trials, by age, but much weaker in Câmpina. In this latter case, a $2^{\text {nd }}$ degree polynomial function better explained the relationship between the independent and dependent variable $\left(R^{2}=0.684\right)$. The marginal populations Beiuş and Marginea stand out in terms of the latewood percentage.

Higher values were recorded for $\% \mathrm{LW} / 5 \mathrm{y}$ in INR trials, but their temporal evolution was different than that in ONR tests (Fig. 3). The largest differences were recorded in the first 15 years after planting (around 16\% between 6-10 years old and 11\% between 11-15 year old), but decreased to $5-6 \%$ up to 25 years. The trend in the last 5 years was a relatively constant 5-6\% difference between INR and ONR.

The experimental data indicate the existence of some interdependencies between radial increments and the production of latewood or earlywood. Therefore, the simple correlations between the periodical average values $\mathrm{RI} / 5 \mathrm{y}$ and $\mathrm{LW} / 5 \mathrm{y}(\mathrm{mm})$ indicated in nearly all testing situations a direct connection between them (Table 3). In the first half of the assessed period, the intensity of these correlations is stronger in the two field trials established in the spruce natural range. The correlations between $\mathrm{RI} / 5 \mathrm{y}$ and $\% \mathrm{LW} / 5 \mathrm{y}$ values (data not shown in table 3) were negative and of low intensity.

\section{Radial increment variability}

There was a greater variability of radial growth in both ONR trials (Table 4). Thus, the mean of CVRI was higher by about 7 units in ONR than in INR field trials. In three out of the four

Table 2. The dynamics of radial growth

\begin{tabular}{|c|c|c|c|c|c|c|c|c|c|}
\hline \multirow[t]{2}{*}{ Trial } & \multirow{2}{*}{$\begin{array}{c}\text { RI } \\
\mathrm{mm} / \\
\text { year }\end{array}$} & \multirow{2}{*}{$\begin{array}{c}\text { RImax } \\
\mathrm{mm} / \\
\text { year }\end{array}$} & \multicolumn{5}{|c|}{ 5-year periodical growth - RI/5y (mm/year) - at the age of: } & \multicolumn{2}{|c|}{$\begin{array}{l}\% \text { decreasing } \mathrm{RI} / \text { last } 5 \text { years } \\
\text { reported from: }\end{array}$} \\
\hline & & & $6-10$ & $11-15$ & $16-20$ & $21-25$ & $26-30$ & RI & RImax \\
\hline \multicolumn{10}{|c|}{ ONR } \\
\hline Avrig & 4.053 & 6.901 & 5.897 & 5.603 & 4.374 & 2.599 & 2.032 & 49.9 & 70.5 \\
\hline Câmpina & 3.713 & 6.096 & 5.980 & 5.562 & 3.785 & 2.660 & 1.877 & 49.4 & 69.2 \\
\hline Mean & 3.883 & 6.499 & & & & & & 49.7 & 69.9 \\
\hline \multicolumn{10}{|c|}{ INR } \\
\hline Brețcu & 4.104 & 6.581 & 5.520 & 5.831 & 4.078 & 2.925 & 2.295 & 44.1 & 65.1 \\
\hline Gurghiu & 3.980 & 6.056 & 5.763 & 5.715 & 4.311 & 3.007 & 2.200 & 44.7 & 63.7 \\
\hline Mean & 4.042 & 6.318 & & & & & & 44.4 & 64.4 \\
\hline
\end{tabular}



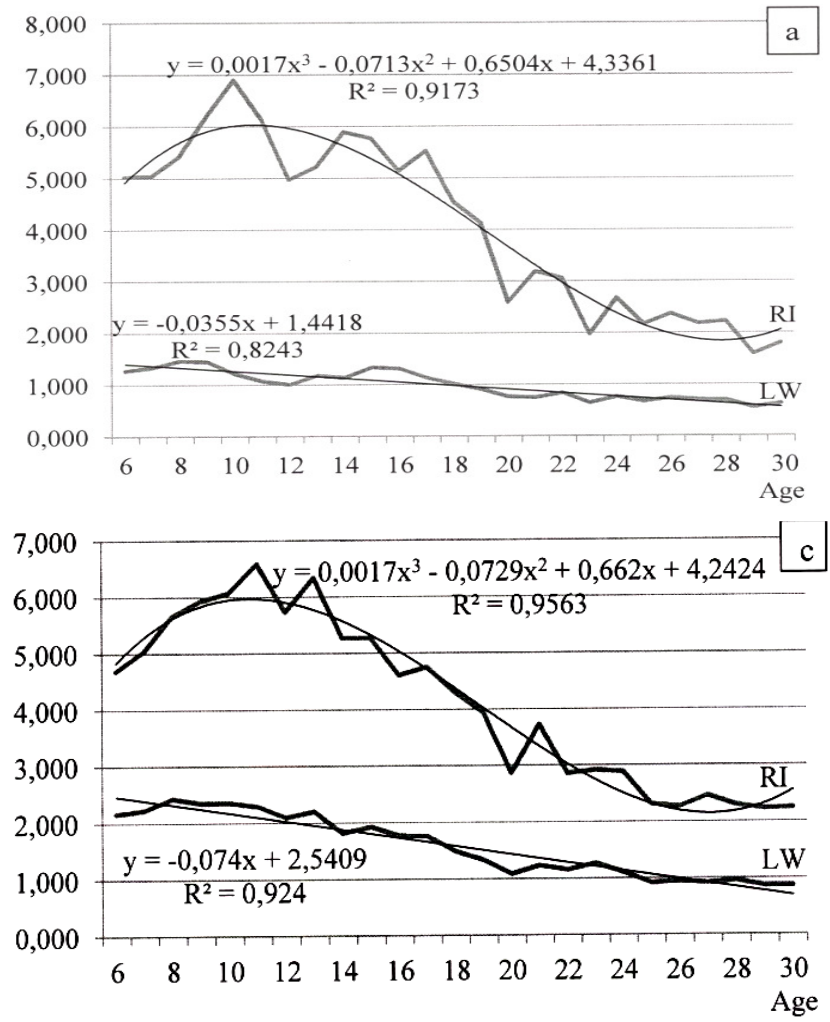
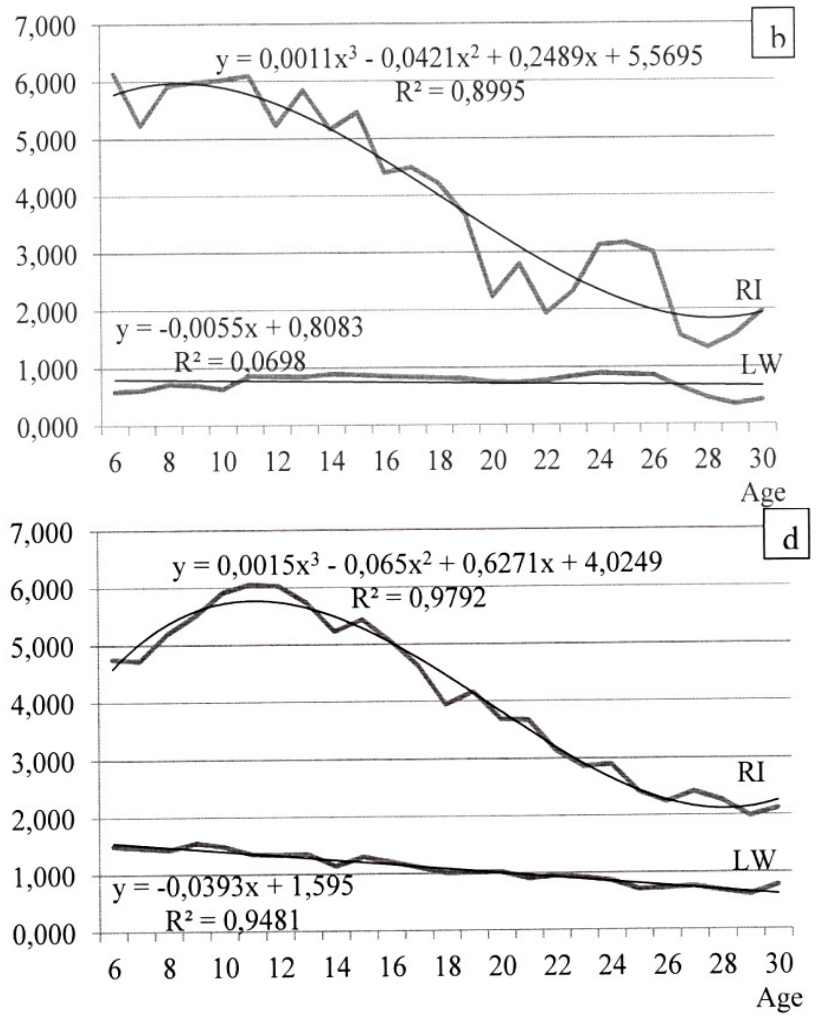

Fig. 1. The dynamics of RI (mm/year) and LW (mm/year) in field trial: a - Avrig; b - Câmpina; c - Brețcu; d - Gurghiu

comparative trials (Brețcu, Gurghiu and Avrig), the average coefficient of variation was slightly higher for EW, compared to CVLW or CVRI. The same situation, but with a much clearer differentiation was recorded in Câmpina test (ONR), where the average coefficient of variation was much higher for $\mathrm{EW}(64.4 \%)$ compared to LW (35.6\%).

The experimental data obtained indicated a lower variability for the annual radial increment in the field trials located in the natural range. This suggests a higher level of adaptive homeostasis in the natural distribution area, which allows a better prediction of biomass production under such conditions. Also, the average coefficients of variation showed higher values for $\mathrm{EW}$ than for $\mathrm{LW}$, the highest difference (of about 30 percentage units) being observed in the Câmpina field trial, outside the natural distribution area. This, once more, suggests the existence of restrictive environmental conditions in this area. On the other hand, inside the natural range, in Gurghiu field trial, the local provenance, for which radial increment was $9.1 \%$ higher than the overall average in this location, showed a reduced variation of annual radial increment $(C V R I=40.0)$. This value, which is by $10.9 \%$ less than the average value of the field trial, suggests a high level of stability of radial increments in the natural and optimal habitat.

Table 3. Correlations matrix between $\mathrm{RI} / 5 \mathrm{y}$ and $\mathrm{LW} / 5 \mathrm{y}$

\begin{tabular}{lccccc}
\hline \multirow{5}{*}{ Field trial Correlation RI/5y-LW/5y in the interval: } \\
\cline { 2 - 6 } & $\begin{array}{c}6-10 \\
\text { years }\end{array}$ & $\begin{array}{c}11-15 \\
\text { years }\end{array}$ & $\begin{array}{c}16-20 \\
\text { years }\end{array}$ & $\begin{array}{c}21-25 \\
\text { years }\end{array}$ & $\begin{array}{c}26-30 \\
\text { years }\end{array}$ \\
\hline In the natural range \\
Avrig & 0.15 & 0.25 & 0.08 & $0.64^{* * *}$ & $0.70^{* * *}$ \\
Câmpina & -0.20 & 0.24 & $0.46^{* *}$ & $0.56^{* * *}$ & $0.36^{*}$ \\
\multicolumn{5}{c}{ Outside the natural range } \\
Brețcu & $0.83^{* * *}$ & $0.81^{* *}$ & $0.73^{* * *}$ & $0.51^{* *}$ & $0.65^{* * *}$ \\
Gurghiu & $0.49^{* *}$ & $0.46^{* *}$ & $0.41^{*}$ & $0.57^{* * *}$ & $0.74^{* * *}$ \\
\hline
\end{tabular}

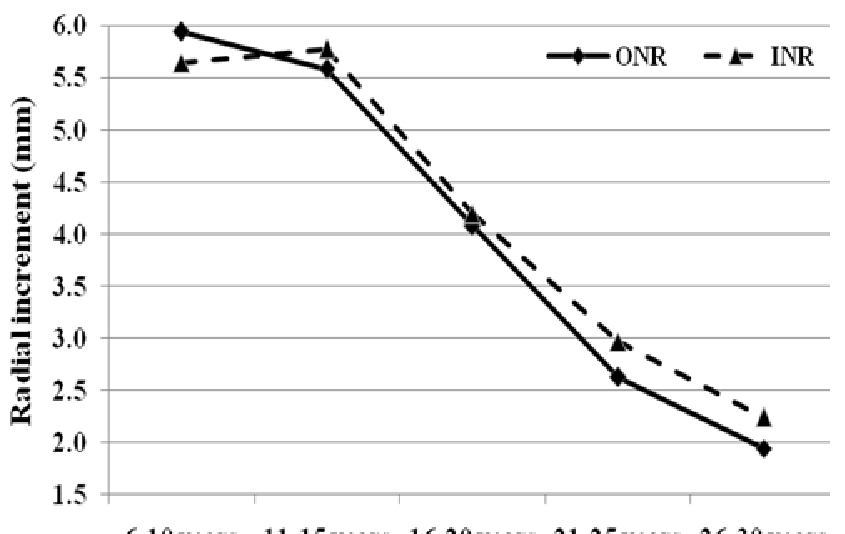

6-10 years 11-15 years 16-20 years 21-25 years 26-30 years

Fig. 2. The dynamics of periodical radial growth (RI/5y) between 6 and 30 years

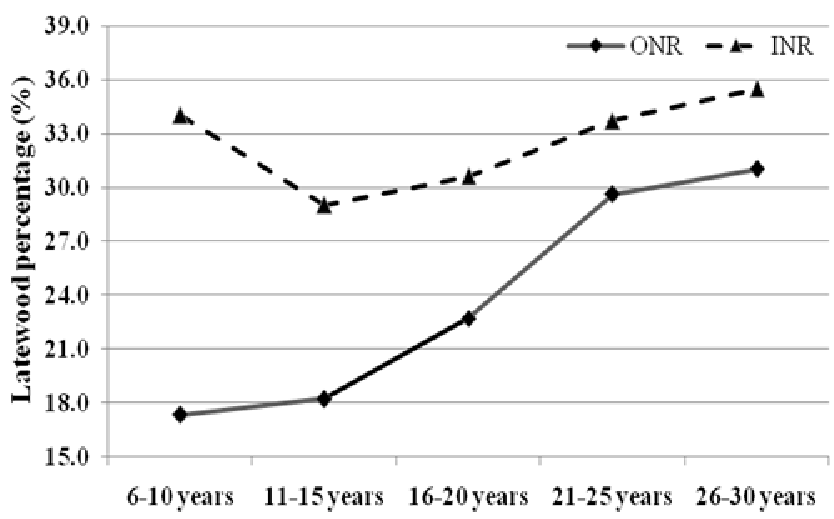

Fig. 3. The dynamics of mean values of latewood proportion (\%LW/5y) 
Table 4. The coefficient of variation for radial growth (CVRI), earlywood (CVEW) and latewood (CVLW)

\begin{tabular}{llcl}
\hline Trial & \multicolumn{1}{c}{ CVRI } & \multicolumn{1}{c}{ CVEW } & CVLW \\
\hline \multicolumn{4}{c}{ In the natural range } \\
\hline Brețcu & 43.6 & 48.4 & 47.3 \\
Gurghiu & 44.9 & 50.4 & 45.0 \\
Mean & 44.2 & 49.4 & 46.1 \\
& Outside the natural range \\
Câmpina & 52.7 & 64.4 & 35.5 \\
Avrig & 49.3 & 56.8 & 52.8 \\
Mean & 51.0 & 60.6 & 44.2 \\
\hline
\end{tabular}

At the same time, a low interpopulational level of variability (CVRI between $8.0 \%$ and 9.6\%) has been determined in all tests, including the two field trials located outside the natural range. On the other hand, compared to INR, the interpopulational variability in ONR tests was higher for latewood $15 \%$ in ONR and $10 \%$ in INR trials). Consequently, in ONR field trials the latewood proportion is lower but the interpopulational variability increased. The lower proportion of latewood at low altitude (ONR), which was negatively correlated with wood density (Jyske et al., 2008; Saranpää, 2003), is a risk factor for spruce stand because of increased cavitations frequency (Hacke $e t$ al., 2001).

\section{Influences of testing site and climatic conditions}

The influence of populations on the mean values of radial increment was not significant $(\mathrm{P}>0.05)$. On the other hand, the testing site showed an important influence $(\mathrm{P}<0.001)$ on the radial growth, including its dynamics evaluated for 5 years intervals (Table 5).

Our determinations revealed important climatic influences on the radial growth both in INR and ONR tests (Table 6). Thus, there was a great and negative influence $(\mathrm{P}<0.001)$ of the average temperature of the growing season on the radial growth, in all four testing sites. However, these influences were significant and more intense in the first half of the growing season $(\mathrm{P}<0.001)$, and became non-significant in the second part of the growing season. At the same time, the radial growth was less influenced by the average precipitation amount of the ongoing or of the previous growing season (non-significant correlations).

Moreover, the populations $x$ localities interaction was highest in the period of maximum radial increment, indicating the possibility of applying juvenile selection to identify the populations with high reaction capacity toward the local environmental conditions.

Norway spruce populations from different areas of its natural and cultivated distribution have been intensively studied with regard to the effects of climatic factors on radial increments and their dynamics (Feliksik and Wilczynski, 2009; Kahle and Spiecker, 1996; Koprowski and Zielski, 2006; Lebourgeois, 2007; Mäkinen et al., 2001; Petráš and Meko, 2011; Rybniček et al., 2010). Thus, in contrasting climatic conditions from southwestern Germany, the annual rings width was strongly correlated with variable climate conditions of the previous year and also of the first half of the growing season in current year; at low altitudes, a negative correlation between rings width and temperature of current summer period was determined (van der Maaten-Theunissen et al., 2013). In southern Norway, at low elevations, the trees growth was restricted by the precipitation from June, while at high altitudes by the temperatures of the same month (Andreassen et al., 2006). Pronounced reactivity of radial growths was recorded along an altitudinal gradient in Norway spruce populations from different parts of its range (Čejková and Kolář, 2009; Mäkinen et al., 2002). Bouriaud et al. (2004) highlighted that intra-annual climate variations influence the radial growths and wood density. Our data indicate a negative influences $(\mathrm{P}<0.001)$ of the average temperature of the growing season on radial growth, in all field trials $\left(\mathrm{r}=-0.58^{* *}\right.$ to $\left.-0.65^{* * *}\right)$, but the influences of the average temperature in the first half of the growing season are stronger than in the second part of it. The negative correlations that have been determined in our study with regard to the influence of temperature in the growing season on radial increments are slightly different from those registered in eastern Finland (Miina, 2000) or in the Austrian Alps (Gindl et al., 2000). These differences may be induced by the reaction of Norway spruce to the ecological specificity of the testing sites.

Table 5. ANOVA for mean radial increment (RI) and for 5-year successive intervals (RI/5y)

\begin{tabular}{|c|c|c|c|c|c|c|}
\hline \multirow[b]{2}{*}{ Source of variation } & \multicolumn{6}{|c|}{ Mean squares $\left(\mathrm{s}^{2}\right)$ for all intervals and for periods of 5 years } \\
\hline & RI & $\begin{array}{c}\mathrm{RI} / 5 \mathrm{y} \\
\text { (6-10 years) }\end{array}$ & $\begin{array}{c}\mathrm{RI} / 5 \mathrm{y} \\
(11-15 \text { years })\end{array}$ & $\begin{array}{c}\mathrm{RI} / 5 \mathrm{y} \\
(16-20 \text { years })\end{array}$ & $\begin{array}{c}\text { RI/ } 5 y \\
(21-25 \text { years })\end{array}$ & $\begin{array}{c}\text { RI/5y } \\
\text { (26-30 years) }\end{array}$ \\
\hline Locality (L) & $9.95^{* * *}$ & $10.1^{* *}$ & $4.9^{* * *}$ & $21.9^{* * *}$ & $11.7^{* * *}$ & $11.09^{* * *}$ \\
\hline Population (P) & 0.29 & 2.01 & 0.90 & 0.84 & $0.86^{*}$ & 0.69 \\
\hline Population $\mathrm{x}$ locality $(\mathrm{P} \times \mathrm{L})$ & $0.47^{* * *}$ & $3.98^{* * *}$ & $1.56^{* * *}$ & $1.00^{* *}$ & $0.78^{* *}$ & 0.64 \\
\hline Error & 0.29 & 2.03 & 0.88 & 0.72 & 0.56 & 0.62 \\
\hline
\end{tabular}

Table 6. Correlations matrix between the radial growth and climatic factors

\begin{tabular}{|c|c|c|c|c|c|c|c|c|}
\hline \multirow{2}{*}{ Climatic factors } & \multicolumn{4}{|c|}{ RI in trial: } & \multicolumn{4}{|c|}{ \%LW in trial: } \\
\hline & Avrig & Câmpina & Brețcu & Gurghiu & Avrig & Câmpina & Brețcu & Gurghiu \\
\hline$\overline{\mathrm{AAT}}$ & $-0.44^{*}$ & -0.39 & $-0.47^{*}$ & $-0.53^{* *}$ & $0.42^{*}$ & 0.27 & -0.13 & 0.34 \\
\hline ATVS & $-0.64^{* * *}$ & $-0.65^{* * *}$ & $-0.63^{* * *}$ & $-0.58^{* *}$ & $0.64^{* * *}$ & $0.58^{* *}$ & 0.04 & 0.39 \\
\hline ATFHVS & $-0.59^{* *}$ & $-0.66^{* * *}$ & $-0.57^{* *}$ & $-0.54^{* *}$ & $0.63^{* * *}$ & $0.68^{* * *}$ & 0.11 & $0.44^{*}$ \\
\hline ATSHVS & -0.33 & -0.25 & -0.28 & $-0.40^{*}$ & 0.26 & 0.09 & -0.08 & 0.17 \\
\hline ATPY & $-0.42^{*}$ & $-0.41^{*}$ & -0.38 & $-0.46^{*}$ & $0.40^{*}$ & 0,24 & -0.13 & $0.48^{*}$ \\
\hline AAP & -0.24 & -0.14 & -0.02 & -0.18 & 0.11 & 0.02 & -0.31 & -0.01 \\
\hline APVS & -0.11 & -0.11 & -0.01 & -0.15 & -0.03 & 0.06 & -0.34 & -0.04 \\
\hline APFPVS & 0.03 & 0.06 & 0.09 & -0.12 & -0.24 & -0.14 & -0.32 & 0.03 \\
\hline APSPVS & -0.23 & -0.27 & -0.19 & -0.11 & 0.27 & 0.27 & -0.17 & -0.11 \\
\hline APPY & -0.29 & -0.22 & -0.08 & -0.17 & 0.26 & 0.20 & -0.12 & 0.09 \\
\hline
\end{tabular}


270

Thus, in the cases analyzed here, it can be assumed that the relatively high temperatures in the first part of the growing season, as in Brețcu and Gurghiu trials, and even higher outside of the natural range, at low altitudes (Avrig and Câmpina trials), had negative effects on the annual ring width. Otherwise, Kahle and Spiecker (1996) identified an inverse correlation between radial growth and potential evapotranspiration from the first part of the growing season, and Petráš and Mecko (2011) reported that the high temperatures in the growing season in general negatively influenced the growth. In Câmpina field trial, where summer temperatures were the highest, the average value of annual radial growth was the lowest, but the CVRI was the highest. At the same time, Mäkinen et al. (2001) indicated a negative correlation between radial growth and the summer high temperatures of the previous year. A similar situation was found in low elevation stands, in south-western Germany (van der Maaten-Theunissen et al., 2013). Moreover, the radial growth was to a lesser extent influenced by the average precipitation amount of the growing season of the current or previous year (non-significant correlations). However, in our study the correlations were negative and of greater intensity in relation to the amount of precipitation from the second half of the growing season, especially in the two comparative field trials located outside the natural range of Norway spruce.

Bouriaud et al. (2004) found a relative independence of wood density from climatic conditions in the first part of the growing season, and on the other hand, the wood density was positively correlated with the proportion of latewood (Bergquist, 1998; Wimmer and Downes, 2003). However, our results showed that the average temperature in the first half of the growing season significantly and positively influenced $(\mathrm{P}<0.001)$ the latewood proportion in the two field trials located outside the natural range $(\mathrm{r}=0.63$ in Avrig trial, $r=0.68$ in Câmpina trial). In the field trials located in the natural range, the influence of the temperature of the first half of the growing season on latewood proportion was lower. Consequently, the formation of latewood started earlier in ONR than in INR field trials. The effect of precipitation in the growing season on the latewood proportion was non-significant. A negative influence of high intensity was determined by the amount of precipitation in August.

\section{Conclusions}

Our study revealed substantial differences in the performance of Norway spruce in experimental field trials located outside and in the natural range. In Norway spruce plantations established outside the natural range we found: a change of radial growth dynamics (reduction of radial growth than in the ecological optimum); a reduction of the latewood proportion, thus affecting the mechanical characteristics and increasing the vulnerability to cavitations (Wolkerstorfer et al., 2010); a greater variability than in the natural range of the width of annual rings, thus reducing the wood homogeneity; a greater amplitude at interpopulational level for CVRIA, at the same site. The temperature in the growing season negatively influenced the radial growth, while the precipitation amount had a small effect. However, the temperature in the first half of the growing season showed a smaller influence on the radial growth in the field trials located in the natural range of the species. This is another argument for the risks of planting Norway spruce outside its natural range in Romania.

\section{References}

Andreassen K, Solberg S, Tveito OE, Lystad SL (2006). Regional differences in climatic responses of Norway spruce (Picea abies L. Karst) growth in Norway. Forest Ecol Manag 222:211-221.

Battipaglia G, Saurer M, Cherubini P, Siegwolf RTW, Cotrufo MF (2009). Tree rings indicate different drought resistance of a native (Abies alba Mill.) and a non-native (Picea abies (L.) Karst.) species co-occurring at a dry site in Southern Italy. Forest Ecol Manag 257:820-828.

Bergquist G (1998). Wood density traits in Norway spruce understory: effects of growth rate and birch shelter wood density. Ann For Sci 55:809-821.

Bouriaud O, Leban JM, Bert D, Deleuze C (2004). Intra-annual variations in climate influence growth and wood density of Norway spruce. Tree Physiol 25:651-660.

Carrer M, Motta R, Nola P (2012). Significant Mean and Extreme Climate Sensitivity of Norway Spruce and Silver Fir at MidElevation Mesic Sites in the Alps. PLoS ONE 7(11):e50755. doi:10.1371/journal.pone.0050755.

Castagneri D, Storaunet KO, Rolstand J (2013). Age and growth patterns of old Norway spruce trees in Trillemarka forest, Norway. Scand J Forest Res 28:232-240.

Čejková A, Kolár T (2009). Extreme radial growth reaction of Norway spruce along an altitudinal gradient in the Šumava Mountains. Geochronometria 33:41-47.

Cook ER, Krusic PJ (2006). ARSTAN4.1b_XP. http://www.ldeo.columbia.edu.

Feliksik E, Wilczynski S (2009). The effect of climate on tree-ring chronologies of native and nonnative tree species growing under homogenous site conditions. Geochronometria 33:49-57.

Gindl W, Grabner M, Wimmer R (2000). The influence of temperature on latewood lignin content in treeline Norway spruce compared with maximum density and ring width. Trees 14:409414.

Hacke UG, Stiller V, Sperry JS, Pittermann J, McCulloh KA (2001). Cavitation fatigue: embolism and refilling cycles can weaken cavitation resistance of xylem. Plant Physiol 125:779-786.

Hannerz M, Westin J (2005). Autumn frost hardiness in Norway spruce plus tree progeny and trees of the local and transferred provenances in central Sweden. Tree Physiol 25:1181-1186.

Holmes RL (1983). Computer-assisted quality control in tree-ring dating and measurement. Tree-ring Bull 43:69-78.

Jyske T, Mäkinen H, Saranpää P (2008). Wood density within Norway spruce Stems. Silva Fenn 42:439-455.

Kahle HP, Spiecker H (1996). Adaptability of radial growth of Norway spruce to climate variations: Results of a site-specific dendrochronological study in high elevations of the Black Forest (Germany), p. 785-801. In: Dean JS, Meko DM, Swetnam TW (Eds). Tree Rings, Environment and Humanity. RADIOCARBON, The University of Arizona.

Kahle HP, Unseld R, Spieker H (2005). Forest ecosystems in a changing environment: Growth pattern as indicators for stability of Norway 
spruce and beyond the limits of its natural range, p. 399-409. In: Bohn U, Hetter C, Gollub G (Eds). Application and analysis of the map of the natural vegetation in Europe. Bonn.

Koprowski M, Zielski A (2006). Dendrochronology of Norway spruce (Picea abies (L.) Karst.) from two range centers in lowland Poland. Trees 20:383-390.

Koski V, Skrøppa T, Paule V, Wolf H, Turok J (1997). Technical guidelines for genetic conservation of Norway spruce (Picea abies (L.) (Karst.). European Forest Genetic Resources Programme (EUFORGEN). International Plant Genetic Resources Institute, Rome, Italy, $51 \mathrm{p}$.

Latalowa M, van der Knaap WO (2006). Late Quaternary expansion of Norway spruce (Picea abies (L.) Karst.) in Europe according to pollen data. Quaternary Sci Rev 25:2780-2805.

Lebourgeois F (2007). Climatic signal in annual growth variation of silver fir (Abies alba Mill.) and spruce (Picea abies Karst.) from the French Permanent Plot Network (RENE-COFOR). Ann For Sci 64:333-343.

Mäkinen H, Nöjd P, Kahle HP, Neumann U, Tveite B, Mielikäinen K, Röhle H, Spiecker H (2002). Radial growth variation of Norway spruce (Picea abies (L.) Karst.) across latitudinal and longitudinal gradients in central and northern Europe. Forest Ecol Manag 171:243-259.

Mäkinen H, Nöjd P, Mielikäinen K (2001). Climatic signal in annual growth variation damaged and healthy stands of Norway spruce (Picea abies (L.) Karst.) in southern Finland. Trees 15:177-185.

Mátyás C, Nagy L, Ujvári-Jármay E (2010). Genetic background of response of trees to aridification at the xeric forest limit and consequences for bioclimatic modelling. Forstarchiv 81:130-141.

Matyssek R, Wieser G, Patzner K, Blaschke H, Häberle KH (2009). Transpiration of forest trees and stands at different altitude: consistencies rather than contrasts? Eur J Forest Res 128:579-596.

Miina J (2000). Dependence of tree-ring, earlywood and latewood indices of Scots pine and Norway spruce on climatic factors in eastern Finland. Ecol Model 132:259-273.

Oleksyn J, Modrzýnski J, Tjoelker MG, Zytkowiak R, Reich PB, Karolewski P (2002). Growth and physiology of Picea abies populations from elevational transects: common garden evidence for altitudinal ecotypes and cold adaptation. Funct Ecol 12:573590.

Olofsson P, Kuemmerle T, Griffiths P, Knorn J, Baccini A, Gancz V, Blujdea V, Houghton RA, Abrudan IV, Woodcock CE (2011). Carbon implications of forest restitution in post-socialist Romania. Environmental Research Letters 6(4), Doi:10.1088/17489326/6/4/045202.

Pacalaj M, Longauer R, Krajmerova D, Gömöry D (2002). Effect of site altitude on the growth and survival of Norway spruce (Picea abies L.) provenances on the Slovak plots of IUFRO experiment 1972. J Forest Sci 48:16-26.

Peichl M, Thevathasan NV, Gordon AM, Huss J, Abohassan RA (2006). Carbon sequestration potentials in temperate tree-based intercropping systems, southern Ontario, Canada. Agrofor syst $66: 243-257$.
Petrás R, Mecko J (2011). Effect of climate factors on the dynamics of radial increments of Norway spruce, European beech and sessile oak. J Forest Sci 57:293-302.

Rybniček M, Čermák P, Žid T, Kolár T (2010). Radial growth and health condition of Norway spruce (Picea abies (L.) Karst.) stands in relation to climate (Silesian Beskids, Czech Republic). Geochronometria 36:9-16.

Saranpää P (2003). Wood density and growth, p. 87-117. In: Barnett JR and Jeronimidis $\mathrm{G}$ (Eds). Wood quality and its biological basis. Blackwell Publishing Ltd, CRC Press, Great Britain.

Saren PM, Serimaa R, Andersson S, Saranpää P, Keckes J, Fratzl P (2004). Effect of growth rate on mean microfibril angle and crosssectional shape of tracheids of Norway spruce. Trees 18:354-362.

Sawa Y, Oleksyn J, Reich PB, Tjoelker MG, Vaganov EA, Modrzyski J (2006). Interannual growth response of Norway spruce to climate along an altitudinal gradient in the Tatra Mountains, Poland. Trees 20:735-746.

Schmidt-Vogt H (1977). Die Fichte. Band I. Taxonomie-VerbreitungMorphologie-Ökologie-Waldgesellschaften. Verlag Paul Parey, Hamburg and Berlin, $647 \mathrm{p}$.

Schütz JP, Götz M, Schmid W, Mandallaz D (2006). Vulnerability of spruce (Picea abies) and beech (Fagus sylvatica) forest stands to storms and consequences for silviculture. Eur J Forest Res 125:291302.

Skrøppa T (1994). Growth rhythm and hardiness of Picea abies progenies of high altitude parents from seed produced at low elevations. Silvae Genet 43:95-100.

Spiecker H (2000). Growth of Norway spruce (Picea abies (L.) Karst.) under changing environmental conditions in Europe, p. 11-26. In: Klimo E, Hager H, Kulhavy J (Eds). Spruce Monocultures in Central Europe: Problems and Prospects. European Forest Institute Proceedings 33.

Steffenrem A, Kvaalen H, Höibö OA, Edvarsen ǾM, Skrøppa T (2009). Genetic variation of wood quality traits and relationships with growth in Picea abies. Scand J Forest Res 24:15-27.

Şofletea N, Budeanu M, Pârnuță G (2012). Provenance variation in radial increment and wood characteristics revealed by 30 years old Norway spruce comparative trials. Silvae Genet 61:170-178.

Şofletea N, Budeanu M (2015). Response of Norway spruce (Picea abies) seed stand progenies tested under different site conditions. Šmarski List 1-2:47-57.

Van der Maaten-Theunissen M, Boden S, Van der Maaten E (2013). Wood density variations of Norway spruce (Picea abies (L.) Karst.) under contrasting climate conditions in southwestern Germany. Ann For Res 56:91-103.

White TW, Adams WT, Neale DB (2007). Forest genetics. CABI Publishing, 682p.

Wimmer R, Downes GM (2003). Temporal variation of the ring width-wood density relationship in Norway spruce grown under two levels of anthropogenic disturbance. Iawa Journal 24:53-61.

Wolkerstorfer S, Rosner S, Hietz P (2010). Assessment of vulnerability to cavitation in small wood samples of Picea abies (L. Karst.). Forestry Ideas 161(39):83-89. 